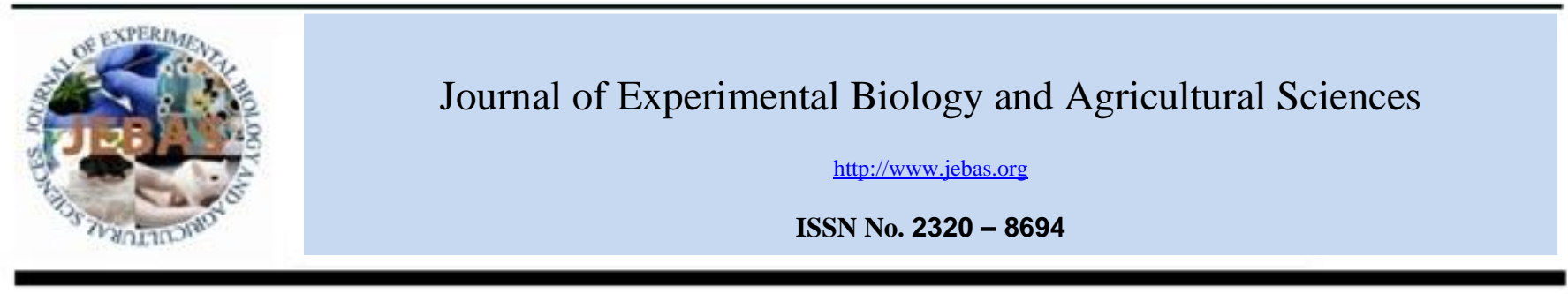

\title{
MODELING THE EFFECT OF MECHANIZATION LEVEL INDEX ON CROP YIELD APPROACHING SYSTEM DYNAMICS METHODOLOGY
}

\section{Behnam Jalalzadeh, Ali Mohammad Borghei* and Morteza Almassi}

Department of Agricultural Mechanization, Science and Research Branch, Islamic Azad University, Tehran, IRAN

Received - February 22, 2016; Revision - March 17, 2016; Accepted - April 13, 2016

Available Online - April 25, 2016

DOI: http://dx.doi.org/10.18006/2016.4(2).169.179

\begin{abstract}
KEYWORDS
Mechanization Level

Modeling

System Dynamics

Farm Crops

Simulation

ABSTRACT

A system dynamics methodology used for estimating effects of mechanization level index on the mean yield of farm crop products, considering the main input and output of farming crops' production system of Iran. A collection of constant parameters, logical relations and statistically estimated functions which were effective in mechanized farm crops' production of Iran, defined as an autonomous system and time span for modeling is defined a period 70-year viz. 1981 up to 2051. Running the established model by simulation software, resulted in key parameters, needed for creating "The production function" as mean yield of farm crop products depended to mechanization level index. After testing validity of the created model, analyzing estimated production function resulted in recognizing three economic production regions. The first economic production region continued from $1.342 \mathrm{Kw} / \mathrm{ha}$ to $2.013 \mathrm{Kw} / \mathrm{ha}$; The second production region started at $2.013 \mathrm{Kw} / \mathrm{ha}$ and ended at $2.386 \mathrm{Kw} / \mathrm{ha}$, and finally the third production region started from $2.386 \mathrm{Kw} / \mathrm{ha}$ for mechanization level Index, while the maximum profitable point for farm crops production appeared at $2.218 \mathrm{Kw} / \mathrm{ha}$ in simulation procedure. All the analysis based on the available statistics for agricultural sector of Iran, since 1981 up to the recent time.
\end{abstract}

* Corresponding author

E-mail: alimohammadborghai@gmail.com (Ali Mohammad Borghei)

Peer review under responsibility of Journal of Experimental Biology and Agricultural Sciences.

Production and Hosting by Horizon Publisher India [HPI] (http://www.horizonpublisherindia.in/).

All rights reserved.
All the article published by Journal of Experimental Biology and Agricultural Sciences is licensed under a Creative Commons Attribution-NonCommercial 4.0 International License Based on a work at www.jebas.org.

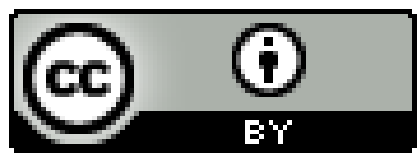




\section{Introduction}

A major advantage of using dynamic simulation approaches is their ability to represent actual processes rather than observed behavior (Neuwirth \& Peck, 2013). The necessity of system dynamics approach for investment analysis and system dynamics application, such as to evaluate different types of investment decisions for developing have been showed previously (Luban, 2009). Due to the nature of machinery inputs, estimation of machinery input based farm crop production dependent on common agricultural economics methods is restricted. The operational field of such experiments for applying mechanization as test inputs should be covered by large-scale regions like a province, state or country.

Furthermore, due to the diversity of planted farm crops' species within a region, using the mechanization level indicators, measured by $\mathrm{Kw} / \mathrm{ha}$, to large scaled areas for observing the effect of input on farm production as output would be so complicated. Thus a system dynamic based method designed for simulating the real situation of the mechanized farming production system of Iran. In a research under the title of "A System Dynamics Model for Evaluating Investment Strategies for Agriculture Development", some strategies planned and tested to optimize the profits from the investment in agriculture system of India (Gupta \& Kortzfleisch, 1987). In a case study, Singh (2006) proposed a linear model about the relationship between the yield and mechanization level index estimated in India for estimation of a mechanization index and its impact on production factors. Additionally, another study for estimating a yield model for irrigated and non- irrigated wheat and barley based on mechanization level indicator in Iran was conducted by Abbasi et al. (2013), result of study revealed an additive relationship for the effect of farm mechanization level, on mean yield of wheat and barley in Iran. Strategic importance of food security issues for each community, forces the relevant sector managers to have a sustaining, Improvement, optimizing and development program for food production. Farm crops have the main role in supplement of inputs for livestock and poultry feeding, dairy industries, edible oil productions and all other the food-processing industries. Use of machinery in farming crop's production, considered as the most expensive input in farming crop's production after land costs (Edwards, 2015).

So this research conducted to focus on defining mechanized farm production collective agents of Iran as a system and a system dynamic modeling used for anticipating real situation by virtual simulating; due to the complexity of changing conditions and environment of farm crop production during time (Fisher et al., 2000). Estimating production function for farm crops of Iran based on machinery inputs, and determining the optimum production point were the main purposes of this research. So that the maximum profitable production point, the maximum capacity of system for physical production and the optimum proposed range for economic production, based on the rate of machinery inputs could be forecasted and determinable.

\section{Materials and Methods}

The main objective of this study was the collection of information involved in mechanized farm crop production in Iran and to establish relationships between them which could form a dynamic autonomous system. Such a conceptually defined system should imitate the real situation regarding the role of machinery in farming procedure, for predicting future conditions acceptably. Cash's liquidity current set as the basic element for designing a dynamic simulating model and a conceptual diagram of cash flow in a system designed so that could illustrate how inputted capital to system converts to mechanization input and then how it converts to farm products and finally to money in an enclosed loop (Figure 1).

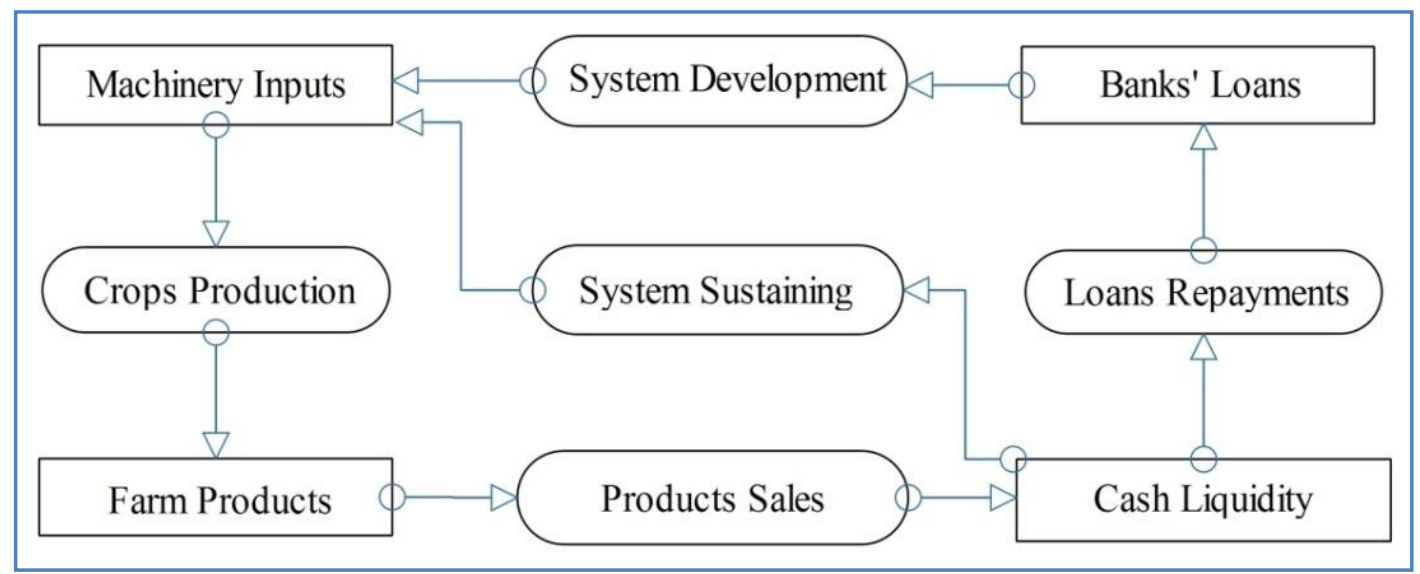

Figure 1 Conceptualization of Cash flow diagram and conversion of money to assets in a mechanized farming production system designed for present research. 
Main structure of this modeling built for predicting future trajectory of involving parameters based on their past trajectory for this all the analysis based on the available statistics for agricultural sector of Iran, since 1981 up to the recent time used in this study. At first step for building simulation model, basic concepts for system creation defined as the diversity of all types of farm crops and farm machinery, a conceptual homologous average value defined and calculated for all various parameters for the machinery function in farm crop production system of Iran.

A collection of 48 commercial mechanized farm crop products of Iran (FAOSTAT, 2015), involving cereals, pulses, oilseeds, vegetables, kitchen garden crops, forage and industrial farm crops defined as material output from the system. Mean yield of farm crop's products through the system, estimated by calculating the ratio of total farm crop's production to the entire cultivated area of farm crops (Eq. 1).

Mean yield of farm crop products through the system $(\mathrm{kg} / \mathrm{ha})=$ (Total farm crops production $(\mathrm{kg}) /$ (Total cultivated area of farm crops (ha)

The portion of total available draft power in system involving draft power of any type of all working 2WD and 4WD farm tractors, combine harvesters and pedestrian controlled (single axle) tractors, to total mechanically cultivated area of farm crops resulted in "The mechanization level index" of the system (Almassi et al., 2008). A time period since 1981 to 2051 defined as a 70-years simulation time span; so that future trajectory of system outputs could be predictable virtually based on the previous trajectory of variable inputs of the system since 1981 to 2014. Then a collection of involved components in mechanized farm crop production of Iran and the relationship between them, gathered as endogenous parameters of the system, and classified in four categories of system inputs:

Category 1: Initial values for system inputs, are values of time independent parameters at the start time of simulation in 1981 (Table 1).
Category 2: Constant system inputs are fixed numerical agents, which assumed to be fixed during simulating time. Considering the generally unchanging nature of the inputs or lack of sufficient statistics about them, was the reason to assuming this category of inputs as the fixed parameters and to be set independent of the time (Table 2).

Category 3: Cause and effect relationship (Sterman, 2000) between each pair of involved parameters, defined as arithmetical functions; so that the cause factor set as independent variable and the effect factor set as the dependent variable of function (Table 3). Intending to create a mathematical relationship between an effect factor and its corresponding cause factor, at first step annually statistics for each variable from related references since 1981 to current time for years 2012, 2013, 2014 or 2015 gathered depending on availability of statistics.

For predicting forthcoming behavior of a time-dependent parameter up to year 2051 based on the previous behavior of that parameter, the Time-Series Analysis (Shumway \& Stoffer, 2011) have been used.

Nine predefined time series models (Embedded in SPSS $®$ ), tested for finding the best fitting model for predicting the future behavior of each time dependent parameter. Captions of the nine tested models were Auto-Regressive Integrated Moving Average (ARIMA) models, Exponential Smoothing Models, Simple, Holt's Linear Trend, Brown's Linear Trend, Damped Trend, Simple Seasonal, Winters' Additive and Winters' Multiplicative. All statistical calculations performed by using SPSS ${ }^{2} 2$ software.

To find out the best-fitting function for relationship between each pair of a cause parameter and its related effect parameter, the Regression Analysis method has been used. Eleven Predefined regression analysis models in analyzing software were Linear, Logarithmic, Inverse, Quadratic, Cubic, Power, Compound, S-Curve, Logistic, Growth model and Exponential models.

Table 1Initial values as the system fixed inputs at the starting time of simulation.

\begin{tabular}{|c|c|c|c|}
\hline "Type of Input as the Initial Value" & "Value" & (Unit) & "Reference of Data" \\
\hline $\begin{array}{l}\text { "Initial Total Compiled Available Motor } \\
\text { Power in System" }\end{array}$ & $5,412,410$ & $(\mathrm{Kw})$ & $\begin{array}{l}\text { Mechanization Development Center of } \\
\text { Ministry of Agriculture of Iran (2015) }\end{array}$ \\
\hline $\begin{array}{l}\text { "Initial Mean Farm Crop Production Unit } \\
\text { Cost" }\end{array}$ & 1.573 & (\$/ha) & The World Bank, 2015 \\
\hline $\begin{array}{l}\text { "Initial Unit Value of Available } \\
\text { Mechanization Capital" }\end{array}$ & 0.675 & $(\$ / \mathrm{Kw})$ & The World Bank, 2015 \\
\hline $\begin{array}{l}\text { "Initial Sales Price Unit Value of Farm } \\
\text { Crop Products" }\end{array}$ & 0.001 & $(\$ / \mathrm{kg})$ & FAOSTAT, 2015 \\
\hline $\begin{array}{l}\text { "Initial Life Unit Cost of a Rural and Urban } \\
\text { Family" }\end{array}$ & 13.682 & (\$/Family) & The World Bank, 2015 \\
\hline
\end{tabular}

Journal of Experimental Biology and Agricultural Sciences

http://www.jebas.org 
Table 2 Inputs of farm crop production system of Iran with fixed values.

\begin{tabular}{|c|c|c|c|}
\hline "Constant Value Input Type" & "Value" & (Unit) & "Reference of Data" \\
\hline $\begin{array}{l}\text { "Draft Power Coefficient (Ratio of available draft power } \\
\text { to Indicated motor power of a tractor)" }\end{array}$ & 75 & $(\%)$ & Almassi et al., 2008 \\
\hline "Mean Annual General Inflation Rate of Iran" & 20.56 & $(\%)$ & The World Bank, 2015 \\
\hline "Total Farm Land to Total Arable Land Ratio" & 81.58 & $(\%)$ & FAOSTAT, 2015 \\
\hline $\begin{array}{l}\text { "Mean Power of a Motor Driven Ambulant Vehicle ( } 4 \\
\text { wheeled Farm Tractors, Combine harvesters and } 2 \\
\text { wheeled Pedestrian tractors)" }\end{array}$ & 61.512 & $(\mathrm{Kw})$ & The World Bank, 2015 \\
\hline "Machine Mean Work Time per Area Unit" & 51.897 & (Kw/ha) & Rajabi et al., 2012 \\
\hline $\begin{array}{l}\text { "Mean Total Technical Worktime of a Motor Equipped } \\
\text { Machine" }\end{array}$ & 11,253 & (Hours) & $\begin{array}{l}\text { American Society of } \\
\text { Agricultural Engineers, } 2000 \& \\
\text { FAOSTAT, 2015 }\end{array}$ \\
\hline "Mean Number of Family Members" & 3.55 & (Person) & FAOSTAT, 2015 \\
\hline $\begin{array}{l}\text { "Number of Farmer Families to Number of all Families } \\
\text { Ratio" }\end{array}$ & 18.88 & $(\%)$ & FAOSTAT, 2015 \\
\hline "Mechanization Rate of Farm Crops" & 71.73 & $(\%)$ & 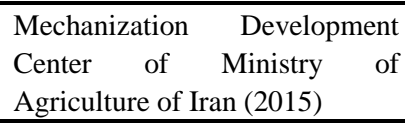 \\
\hline $\begin{array}{l}\text { "Total Machinery Costs as Percent of Total farm crops } \\
\text { Production Costs" }\end{array}$ & 21.1 & $(\%)$ & Abbasi et al., 2011 \\
\hline "Number of Loan Repayments" & 5 & (1/Year) & Agriculture Bank of Iran, 2015 \\
\hline "Total Loan Repayment Time" & 5 & (Dimensionless) & Agriculture Bank of Iran, 2015 \\
\hline "Banks Loan Yearly Mean Interest Rate" & 15 & $(\%)$ & Agriculture Bank of Iran, 2015 \\
\hline $\begin{array}{l}\text { "Fixed Costs of a Machine as Percent of Total Machine } \\
\text { Costs" }\end{array}$ & 64.89 & $(\%)$ & Ashtiani et al., 2006 \\
\hline $\begin{array}{l}\text { "Mean Yearly Paid Loans by Banks for Farm } \\
\text { Machinery Supplement as a Percent of GDP" }\end{array}$ & 0.0311 & $(\%)$ & 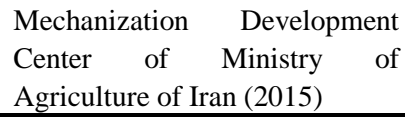 \\
\hline $\begin{array}{l}\text { "Portion of Farmers Revenue Spend for Mechanization } \\
\text { Development" }\end{array}$ & 0 & $(\%)$ & $\begin{array}{lr}\text { Information } & \text { and } \\
\text { Communication } & \text { Technology } \\
\text { Center for Ministry of } \\
\text { Agriculture of Iran (2012) }\end{array}$ \\
\hline
\end{tabular}

Table 3 The cause and effect relation formulation between the system internal parameters.

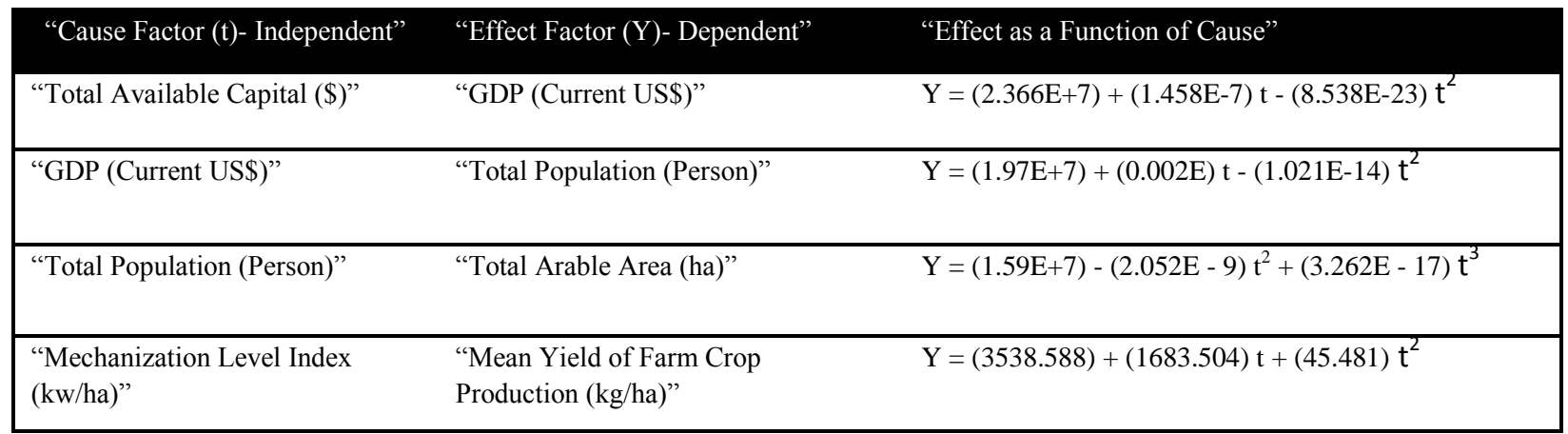


Category 4: A collection of 33 logical relationships between input and outputs of the designed system defined as below:

1. Mechanization level $(\mathrm{Kw} / \mathrm{ha})=$ Total Available Draft Power (Kw) / Total Farm Area (ha)

2. Total Available Draft Power $(\mathrm{Kw})=$ Total Available Mechanical Power (Kw)/ Draft Power Coefficient $(\%) \times 100$

3. Total Mass of Farm Products $(\mathrm{kg})=$ Mean Yield of Farm Products $(\mathrm{Kg} / \mathrm{ha}) \times$ Total Farm Area (ha)

4. Farm Production Total Costs $(\$)=$ Total Farm Area (ha) $\times$ Mean Farm Production Unit Cost $(\$ / \mathrm{ha})$

5. Fully Mechanized Production Costs $(\$)=$ Farm Production Total Costs $(\$) \times$ Mechanization Rate $(\%) / 100$

6. Farm Production Total Mechanization Costs $(\$)=$ Fully Mechanized Production Costs $(\$) \times$ Total Mechanization Cost Percent of Total Production Cost (\%)/100

7. Total System Fixed Costs $(\$)=$ Farm Production Total Mechanization Costs $(\$) \times$ Fixed Costs as Percent of Total Costs $(\%) / 100$

8. Total Farming System Costs $(\$)=$ Farm Production Total Costs (\$) + Total Loan Repayment (\$) + Total Life Costs (\$)

9. Initial Net Revenue of Farm Production $(\$)=$ Initial Gross Revenue (\$) - Initial Total Costs (\$)

10. Number of Total Families $($ Family) $=$ Total Population (Person)/ Mean Number of Family Members (Person/Family)

11. Net Revenue of Farm Production $(\$)=$ Total Revenue Rate (\$) - Total Costs Rate (\$) + Initial Net Revenue of Farm Production (\$)

12. Total Gross Revenue of Farming $(\$)=$ Unit Sales Price of Farm Products $(\$ / \mathrm{kg}) \times$ Total Production of Farm Products (kg)

13. Inputted power to Mechanization System $(\mathrm{Kw})=$ Inputted Capital into Mechanization System (\$) / Unit Value of Mechanization Capital $(\$ / \mathrm{Kw})$

14. Value of Total Available Capital in Mechanization System $(\$)=$ Total Available Mechanical Power $(\mathrm{Kw}) \times$ Unit Value of Mechanization Capital $(\$ / \mathrm{Kw})$

15. Number of Farmer Families $=$ Farmer Families Ratio $(\%) \times$ Number of Total Families /100

16. Total Available Mechanical Power $(\mathrm{Kw})=$ Total Power Input Rate $(\mathrm{Kw})$ - Total Power Exit Rate $(\mathrm{Kw})$ + Initial Compiled Power (Kw)

17. Initial Power Exit $(\mathrm{Kw})=$ Initial Compiled Power $(\mathrm{Kw}) /$ Expected Lifetime of a Machine (Year) $\times$ Time Step (Year)

18. Current Power Exit $(\mathrm{Kw})=$ Delaying Input Power to Mechanization System (Kw) equal to Expected Lifetime of a Machine

19. Total Power Exit $(\mathrm{Kw})=$ Initial Power Exit $(\mathrm{Kw})$, up to Expected Lifetime of a Machine + Current Power Exit (Kw), after Expected Lifetime of a Machine.

20. Number of all Tractors, Combine harvesters and Pedestrian Controlled Tractors $=$ Total Available Mechanical Power $(\mathrm{Kw})$ / Mean Power of a Machine (Kw).

21. Yearly Work time of a Machine (hour/Year) = Total Required Work Time of System (hour/Year) / Number of Tractors, Combine harvesters and Pedestrian Controlled Tractors
22. Mechanization Development Capital $(\$)=$ Mechanization Development Costs as Percent of Total Net Revenue of Farm Production $(\%) \times$ Net Revenue of Farm Production (\$) /100 + Banks Finances Input (\$)

23. The inputted capital into Mechanization System (\$) = Mechanization Development Capital (\$) + Total System Fixed Costs $(\$)$

24. Total System Fixed Costs $(\$)=$ Farm Production Total Mechanization Costs $(\$) \times$ Fixed Costs as Percent of Total Costs $(\%) / 100$

25. Total Banks Finances Input $(\$)=$ GDP $($ Current US\$) $\times$ Total Bank Finances as Percent of GDP (Current US\$) (\%) / 100

26. Total Required Work Time of System (hour/Year) $=$ Total Farm Area (ha) $\times$ Power Work Time per Area Unit (hour/ha/Year)

27. Expected Lifetime of a Machine (Year) $=$ Total Technical Work time of a Machine (hour) / Yearly Work time of a Machine (hour/Year)

28. Total Farm Area (ha) = Farm Land to Arable Land Ratio $(\%) \times$ Total Arable Area (ha) / 100

29. Total Farming System Costs $(\$)=$ Total Loan Repayment $(\$)+$ Farm Production Total Costs $(\$)+$ Total Life Costs $(\$)$

30. Each Loan Installment Value $(\$)=$ "Banks Finances Input (\$)" × ("Total Repayment Time"+1) ×"Loan Interest Rate (\%) /200) +"Banks Finances Input") / "Number of total Repayments"

31. Repayment Step $=$ Total Repayment Time / Number of Repayments

32. Total Population $($ Person $)=$ Effect of GDP on Population $($ Person $\$$ ) $\times$ GDP $($ Current US\$)

33. Mean Yield of Farm Products $(\mathrm{kg} / \mathrm{ha})=$ Effect of Mechanization Index on Yield $(\mathrm{kg} / \mathrm{Kw}) \times$ Mechanization level (Kw/ha)

All defined fixed and variable parameters and relations in categories 1, 2, 3 and 4 assembled as a dynamic system for simulation and predicting future values of both dependent and independent parameters of production function of Iran's farming production system.

The conceptually designed model by using the simulation software "Vensim ${ }^{\circledR}$ PLE 6.3" were converted to an applicable software (Figure 2).

\section{Results and Discussion}

Overall structure of the system consisted of 95 input and output parameters among these 5 are initial value type inputs, 14 constant value type inputs, 6 Level type parameters and 70 are Auxiliary type parameters (Ventana Systems, Inc. 2007). Furthermore, four causes and effect type functions, and 33 logically defined relations, finally assembled as basic structure of agricultural machinery utilization for the mechanized production of farm crops in Iran. 


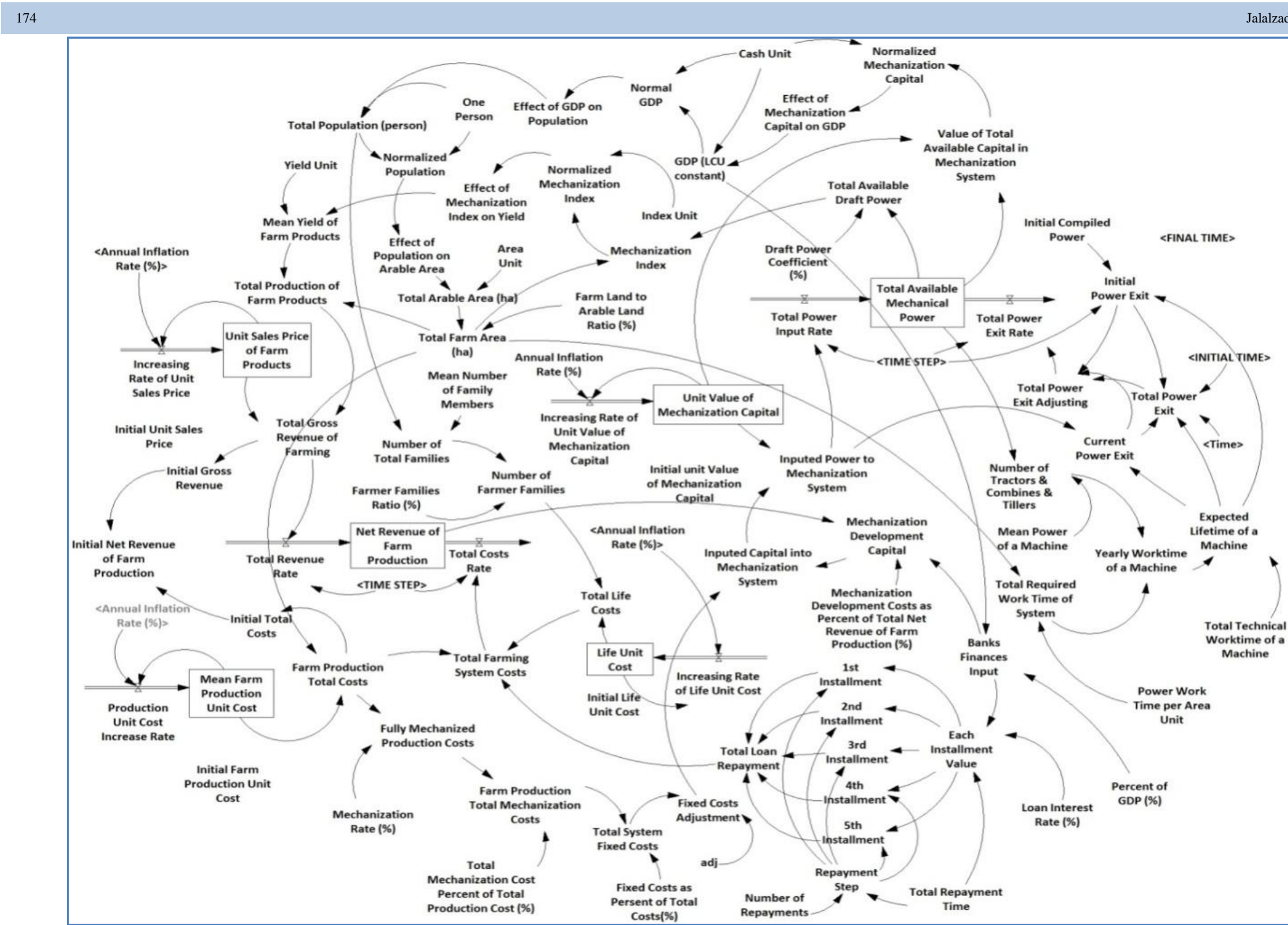

Figure 2 Operational Schematic of the main simulation model built by Vensim 6.3 PLE simulation software. 
Table 4 Comparative results for outputs of the modeled system vs real situation for point wise validation test of system outputs.

\begin{tabular}{|c|c|c|c|c|}
\hline "Test Parameter" & $\begin{array}{l}\text { According to the } \\
\text { Measured } \\
\text { Records at } 2011\end{array}$ & $\begin{array}{l}\text { Vensim Output for } \\
\text { Simulation Model } \\
\text { at } 2011\end{array}$ & $\begin{array}{l}\text { Model Output and } \\
\text { Measured Records } \\
\text { Difference }\end{array}$ & $\begin{array}{l}\text { "Percent of } \\
\text { Difference } \\
(\%)\end{array}$ \\
\hline Value of Total Available Machines (\$) & $4,962,974,123$ & $5,599,450,215$ & $636,476,091$ & 12.82 \\
\hline Total Available Motor Power (Kw) & $35,126,904$ & $30,348,299$ & $-4,778,605$ & -13.6 \\
\hline "Total Available Draft Power (Kw) & $26,345,178$ & $22,761,225$ & $-3,583,953$ & -13.6 \\
\hline Total Arable Land Area (ha) & $17,541,000$ & $18,564,676$ & $1,023,676$ & 5.84 \\
\hline Mechanization Level of System (Kw/ha) & 1.502 & 1.503 & 0.001 & 0.064 \\
\hline $\begin{array}{l}\text { Unit Value of Mechanization Capital } \\
(\$ / \mathrm{Kw})\end{array}$ & 186.175 & 184.506 & -1.669 & -0.9 \\
\hline GDP (Current US\$) & $18,838,322,969$ & $17,926,061,905$ & $-912,261,064$ & -4.84 \\
\hline Total Farm Crop Yearly Production $(\mathrm{Kg})$ & $72,007,472,000$ & $76,165,242,880$ & $4,157,770,880$ & 5.77 \\
\hline $\begin{array}{l}\text { Mean Yield of Farm Crop Production } \\
(\mathrm{kg} / \mathrm{ha})\end{array}$ & 5,152 & 5,029 & -123 & -2.39 \\
\hline System Population (Person) & $74,799,000$ & $76,624,552$ & $1,825,552$ & 2.44 \\
\hline $\begin{array}{l}\text { Mean Life Costs of Rural \& Urban } \\
\text { Families (\$) }\end{array}$ & $3,705.99$ & $3,734.69$ & 28.696 & 0.77 \\
\hline $\begin{array}{l}\text { Total Number of all Tractors, Combine } \\
\text { Harvesters and other Power driven } \\
\text { vehicles (Set) }\end{array}$ & 553,098 & 493,375 & $-59,723$ & -10.8 \\
\hline Mean Farm Crop Production Costs (\$/ha) & 429.365 & 429.489 & 0.123 & 0.03 \\
\hline Power Inputting to System (Kw) & 916,416 & 779,851 & $-136,565$ & -14.9 \\
\hline \multicolumn{4}{|c|}{ Mean difference of 14 forecasted parameters and related really records in $2011(\%)$} & 6.34 \\
\hline
\end{tabular}

For checking the reality of system behavior and validating functionality of the built model response, four static and three dynamic tests have been done. As a static test, the built system at first step should be capable of predicting the values of system output parameters in a specified previous time section which statistical data for the same outputs had been recorded at that time previously. Collating system output for a number of 14 parameters in the year 2011 through the running software with the registered statistics for the same items resulted that the built system could predict the value of 14 outputs of the system by mean error of $\pm 6.34 \%$ different from the mean of really recorded values in 2011 (Table 4).

Examining of the ten predefined regression models for relationships between crop yield and mechanization level index (Embedded in SPSS ${ }^{\circledR}$ 22) based on simulation model outputs for these parameters, resulted in the effect of "The mechanization level Index" on "The mean yield of 48 farm crop products."

The arithmetic relation determined as a third-degree polynomial formula in this study (Eq. 2)

$\mathrm{Y}=3406.087-1316.370 \mathrm{t}+1827.328 \mathrm{t}^{2}-337.958 \mathrm{t}^{3}$

... (2)
(The equation "2" assumed as production function formulae and some testes implemented to show the reality of this assumption in continue).

In comparison the results of this research with the results of other correspondent studies, the effect of mechanization level on mean yield of irrigated and non-irrigated wheat and barley in this study, compared with results of same previous studies. So the mean yield of both irrigated and non- irrigated wheat and barley were as the ratio of $41 \%$ of The mean farm crops yield, so the effect of mechanization level index on the mean yield of food grain crops estimated as a triple degree nonlinear function by multiplying equation "2" by 0.41 (Eq. 3)

$$
\begin{gathered}
\mathrm{Y}=1872.755-970.555 \mathrm{t}+1806.699 \mathrm{t}^{2}-448.092 \mathrm{t}^{3} \\
\ldots \text { (3) }
\end{gathered}
$$

In a case study in India for estimation of the mechanization level index and its impact on farm production factors, a linear model has been proposed for establishing the relationship (Eq. 4) between the yield of food grains and the mechanization level index (Singh, 2006).

$\mathrm{Y}=708.97+911.65 \mathrm{t}$

Where; $\quad 0.40 \mathrm{Kw} / \mathrm{ha} \leq \mathrm{t} \leq 2.80 \mathrm{Kw} / \mathrm{ha}$ 
Furthermore, another study for estimating the yield model of both, irrigated and non-irrigated wheat and barley based on mechanization level indicator in Iran, resulted a linear relationship (Eq. 5) for the effect of farm mechanization level, on mean yield of wheat and barley in Iran (Abbasi et al., 2013).

$\mathrm{Y}=625.7+798.65 \mathrm{t}$

Where; $0.477 \mathrm{Kw} / \mathrm{ha} \leq \mathrm{t} \leq 2.073 \mathrm{Kw} / \mathrm{ha}$

Consistency with the basic reference patterns of agricultural production (Sterman, 2000) is another proof for validation of the established model. To test this capability of the model, by continuous increasing of the system leading input, the amount of main system output should be initially increased and after reaching the maximum point, it should be starting to decrease.

Comparison results showed that against the current research, both previously proposed linear models (Singh, 2006) and (Abbasi et al., 2013) didn't fulfill the principle of diminishing returns in agricultural production economics (Figure 3 ).
2) as a production function of the system, some criteria which should be fulfilled. (Debertin, 1985) are $1^{\text {st }}$ should have a thirddegree polynomial formula for the production function; $2^{\text {nd }}$ it should be consistent with the principle of diminishing returns' law in agricultural production economics for both physical production and net profit; $3^{\text {rd }}$ it should involved in three standard production regions and $4^{\text {th }}$, The maximum profitable production point should fall in the second region of production function.

The maximum value for mean yield of 48 types of farm crops was $9,161 \mathrm{~kg} / \mathrm{ha}$, while the mechanization level index reached to $2.386 \mathrm{Kw} / \mathrm{ha}$. These results fulfilled the principle of diminishing returns in agricultural production economics (Colman \& Young, 1989). Ratio of net revenue of total farm crop production to total available capital in system as mechanization inputs (A dimensionless parameter for omitting yearly inflation effects of prices) defined as "Economic Effectiveness of the Mechanized Farming Production System of Iran".

For establishing relationship between the mechanization level for farm crop production and the mean yield of farm crops (Eq.

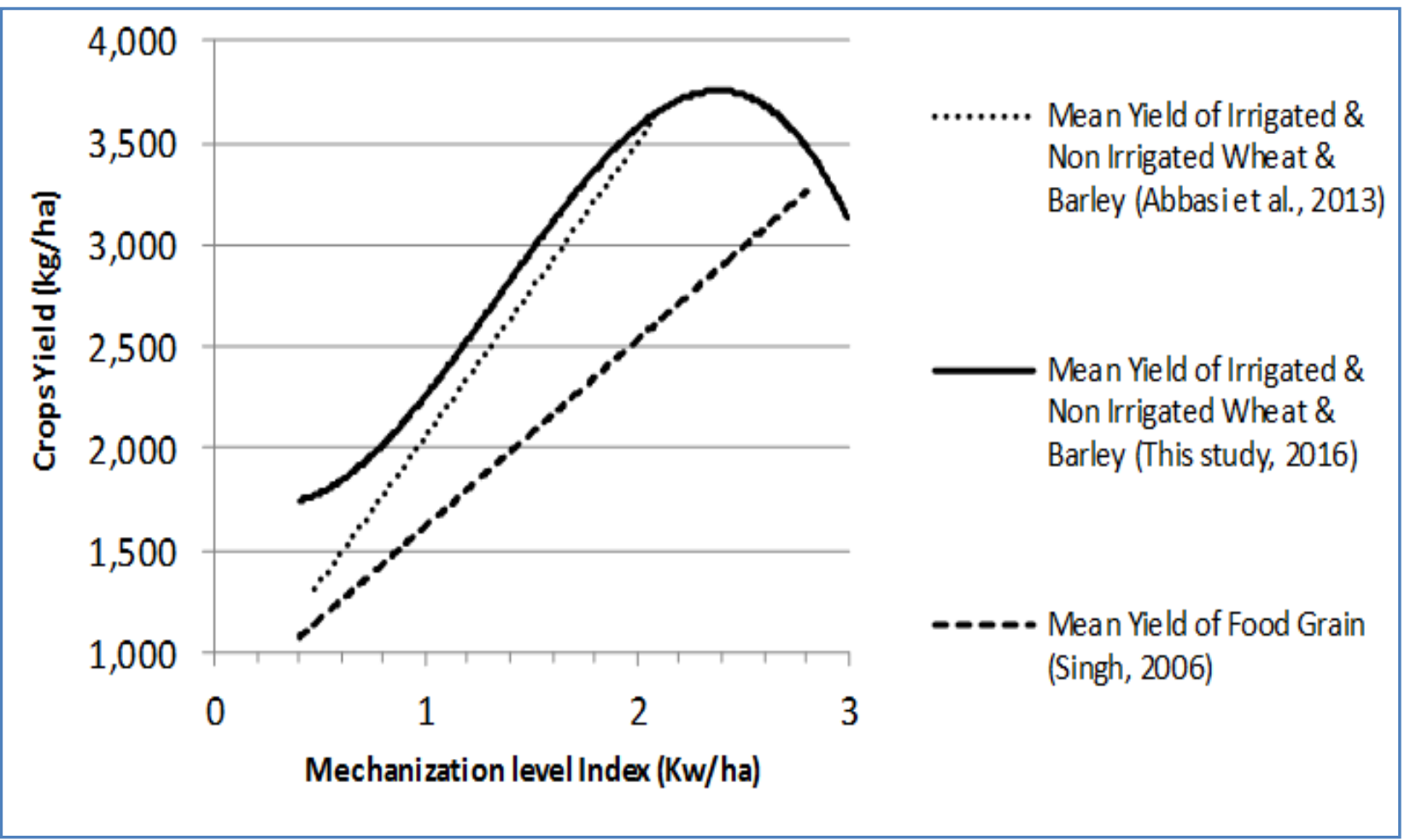

Figure 3: Graphical comparative results of this study and previous studies on the response of mean yield of food grain crops vs changes in the mechanization level index. 


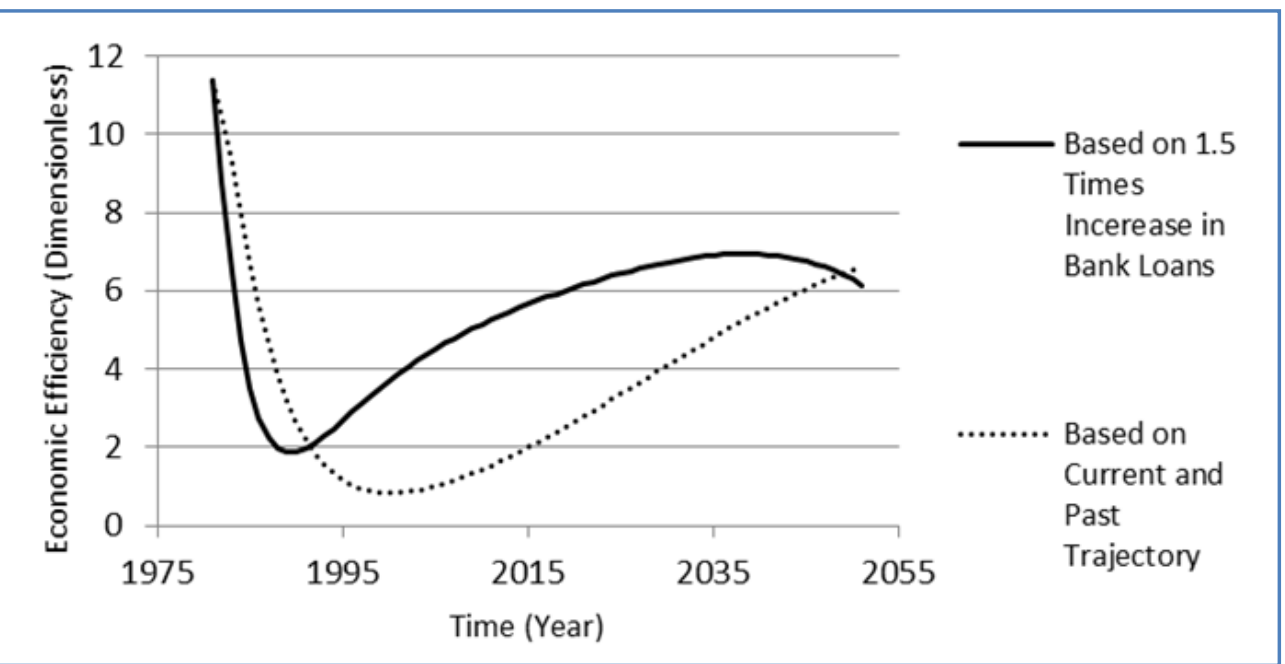

Figure 4 The maximum economic efficiency of system while overloaded by increase in banks loans to find the optimum value of mechanization level Index (2.218 Kw/ha).

Running the established model based on current values for all inputs, didn't result in maximum point of economic efficiency. Then to find the maximum value for economic efficiency, system overloaded by banks' loans increase up to $150 \%$ of current value, as input from start time to end time of simulation. Results of this experiment showed that the maximum reachable value for defined economic efficiency of the system will appear on year 2040 as 7.0 (dimensionless), while at this time mechanization level index will reach to 2.218 $\mathrm{Kw} / \mathrm{ha}$ as the maximum point for the net profit of production (Figure 4).

For diagnosis the three economic production regions (Colman \& Young, 1989), the mean yield of farm crop products (Eq. 2) set as equal to the total physical product (T.P.P) of the system (Eq. 6).

T.P.P $=3406.087-1316.370 \mathrm{t}+1827.328 \mathrm{t}^{2}-$ $337.958 \mathrm{t}^{3}$
The Marginal physical product (M.P.P), calculated by first derivation of total physical product (Eq. 7).

M.P.P $=-1316.370+3654.656 \mathrm{t}-1013.874 \mathrm{t}^{2}$

Also the average physical product (A.P.P) calculated as ratio of "The total physical product" to "t" (The Mechanization level index), (Eq. 8).

A.P.P $=-1316.370+1827.328 t-337.958 t^{2}$

According to the equations (6), (7) and (8) the first economic production region begins from 0 up to $2.013 \mathrm{Kw} / \mathrm{ha}$ for mechanization level Index, which consisted of two regions, from 0 up to $1.342 \mathrm{Kw} / \mathrm{ha}$ (Maximum value of M.P.P) and from 1.342 up to $2.013 \mathrm{Kw} / \mathrm{ha}$ (Maximum value of A.P.P). The second economic production region begins from 2.013 up to $2.386 \mathrm{Kw} / \mathrm{ha}$ (Maximum value of T.P.P). Finally, the third production region begins from $2.386 \mathrm{Kw} / \mathrm{ha}$ (Table 5).

Table 5 The boundary values of Production Function and distinguishing three economic production regions.

\begin{tabular}{lllll} 
Maximum Value & T.P.P. & M.P.P. & A.P.P. & Profit of Production \\
$\begin{array}{l}\text { The Boundary Values } \\
\text { of Production }\end{array}$ & $\begin{array}{l}\text { Start of 3rd Economic } \\
\text { Function }\end{array}$ & $\begin{array}{l}\text { Start of 2nd Part of } \\
\text { Prt Economic } \\
\text { Production Region }\end{array}$ & $\begin{array}{l}\text { Start of 2nd } \\
\text { Economic } \\
\text { Production Region }\end{array}$ & $\begin{array}{l}\text { Maximum Economic Efficiency } \\
\text { of Production }\end{array}$ \\
\hline $\begin{array}{l}\text { Mechanization Level } \\
\text { Index (Kw/ha) }\end{array}$ & 2.386 & 1.342 & 2.013 & 2.218 \\
\hline
\end{tabular}




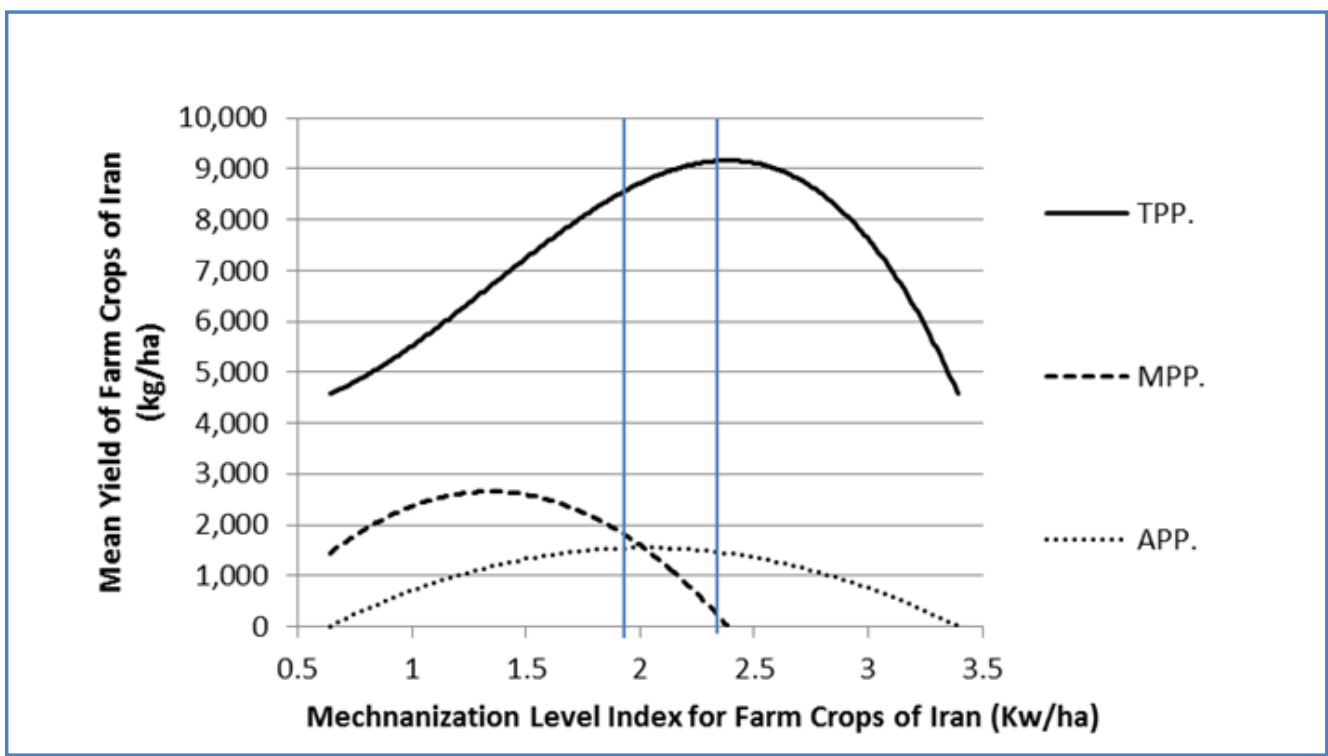

Figure 5 Triple production regions for the production function of farm crops as depended to machinery Input

Because of estimating the maximum profitable production point of system equal to $2.218 \mathrm{Kw} / \mathrm{ha}$ by dynamically overloading the system cash input in simulation procedure (Figure 4), and calculating the maximum value of T.P.P and A.P.P as 2.386 and $2.013 \mathrm{Kw} / \mathrm{ha}$ respectively, thus the maximum profitable production point of system fell at second production function for farm crops of Iran. This run of model fulfilled the 4th condition as mentioned in "Developing Realistic Agricultural Production Functions" (Debertin, 1985). And due to estimating accuracy rate of model outputs for the system mean total outputs as $93.66 \%$ in comparison to the recorded actual values in 2011 (Table 4), the total estimation error of production function of Iran's farm production system estimated as $6.34 \%$ in comparison to the recorded values in real situation (Eq. 9).

$$
\begin{gathered}
" 2.013(\mathrm{Kw} / \mathrm{ha}) \pm(6.34 \%) " \leq \text { "2.218(Kw/ha) } \pm(6.34 \%) " \leq \\
\text { "2.386(Kw/ha) } \pm(6.34 \%) " \\
\ldots \text { (Eq. } 9)
\end{gathered}
$$

\section{Conclusion}

Results showed that due to the restrictions of field experiments, estimating a valid production function of farm crop products as the yield index depended to mechanization level index, could be accomplished by using a virtual modeling based on system dynamics approach. The estimated function for Iran's farm crops production (Eq.2 same as Eq. 6) was consistent with results of previous studies and fulfilled the basic principles of agricultural production economics.

Finally analyzing the created production function resulted that, the maximum profitable point for farming production system of Iran based on machinery input, will occur by 2.218 $( \pm 6.34 \%)$ as $\mathrm{Kw} / \mathrm{ha}$ for the value of mechanization level index. And the physical production of the yield index will exceed to its maximum value, while the mechanization level index as the main input could increase up to $2.386( \pm 6.34 \%)$ as $\mathrm{Kw} / \mathrm{ha}$ with the probability level of $100 \%$.

Recommended region for farm crops production in Iran, defined as "Second Economic Production Region" from $2.013(\mathrm{Kw} / \mathrm{ha}) \pm(6.34 \%)$ up to $2.386(\mathrm{Kw} / \mathrm{ha}) \pm(6.34 \%)$ considering the machinery input.

Comparing the results of this study with the current value of mechanization level index $(0.895 \mathrm{Kw} / \mathrm{ha})$ showed that, at least there is a need to increase mechanization level index of the system by $1.323( \pm 6.34 \%)$ as $\mathrm{Kw} / \mathrm{ha}$ to reach the maximum profitable point for farming production system of Iran.

\section{Conflict of interest}

Authors would hereby like to declare that there is no conflict of interests that could possibly arise.

\section{References}

Abbasi K, Almassi M, Borghai AM, Minaii S (2013) Estimating yield model of main farm crops based on mechanization level indicator in Iran, Journal of Agricultural Machinery 4: 344-351 Retrieved from http://jame.um.ac.ir/index.php/jame/article/view/34826 on January 2016.

Abbasi S, Gholami M, Rashidi M (2011) Comparison of methods for semi-mechanized and mechanized economic production of irrigated wheat in the city Kaboudarahang, First National Conference on new issues in agriculture, Islamic Azad University, Saveh Branch, Iran, October 2011. 
Agriculture Bank of Iran (2015) Retrieved from http://www.bki.ir/Portals/0/SBank/AgriBankActivities.pdf on 15 August 2015

Almassi M, Kiani SH, Loveimi N (2008) Principles of Agricultural Mechanization, Tehran: Jungle Javedaneh

American Society of Agricultural Engineers (2000) ASAE D497.4 MAR99, Agricultural Machinery Management Data, 354, Retrieved from http://www.nrcs.usda.gov/Internet/FSE_DOCUMENTS/16/nrc s143_009503.pdf on 15 August, 2015

Ashtiani AR, Ranjbar I, Toorchi M (2006) Determining the economic life of the three models of farm tractors in Iran. Journal of Agricultural Sciences, 12: 221-230.

Colman D, Young T (1989) Principles of Agricultural Economics, Cambridge: Cambridge University Press 2: 5-29.

Debertin LD (1985) Developing Realistic Agricultural Production Functions for Use in Undergraduate Classes, Southern Journal of Agricultural Economics, 17: 207-213, Retrieved from http://ageconsearch.umn.edu/bitstream/29983/1/17020207.pdf on 22 August, 2015.

Edwards W (2015) PM-710 estimating Farm Machinery Costs, Iowa State University Extension, Retrieved from http://www.econ.iastate.edu/research/extension/p7155 on 15 August, 2015

FAOSTAT, (2015) Food and Agriculture Organization of the United Nations, Retrieved from http://faostat3.fao.org/download/Q/QC/E on 15 August, 2015

Fisher DK, Norvell J, Sonka S, Nelson MJ (2000) Understanding technology adoption through system dynamics modeling: implications for agribusiness management. International Food and Agribusiness Management Review 3: 281-296.

Gupta G, Kortzfleisch G (1987) a System Dynamics Model For Evaluating Investment Strategies for Agriculture Development, Computer Science and Systems Analysis: Technical Report, Miami University, Retrieved from
https://sc.lib.miamioh.edu/bitstream/handle/2374.MIA/192/full

text.pdf?sequence $=2 \&$ isAllowed=y on 14 December, 2015

Information and Communication Technology Center for Ministry of Agriculture of Iran (2012) Agricultural Statistics, 2 : 32-68, Retrieved from http://www.maj.ir/Portal/File/ShowFile.aspx?ID=6f66d3e30884-4823-b12d-6319a2edad84 on 15 August 2015

Luban F (2009) Using simulation to evaluate Investment projects: Proceeding of the Ninth International Conference on Investments and Economic Recovery, Bucharest, Romania, May 22-23, 2009, 139-144

Mechanization Development Center of Ministry of Agriculture of Iran (2015) Retrieved from http://www.agmdc.ir/HomePage.aspx?TabID=4843\&Site=Ajm dcPortal\&Lang=en-US on 15 August 2015

Neuwirth C, Peck A (2013) A conceptual spatial system dynamics (SSD) model for structural changes in grassland farming. 20th International Congress on Modelling and Simulation, Adelaide, Australia, 1-6 December 2013, 628-634.

Rajabi MH, Soltani A, Zeinali E, Soltani E (2012) Assessment of energy consumption in the production of wheat in Gorgan. Journal of Plant Production Research 19 : 143-171.

Shumway RH, Stoffer DS (2011) Time Series Analysis and Its Applications, New York, NY, Springer

Singh G (2006) Estimation of a Mechanization Index and Its Impact on Production and Economic Factors (A Case Study in India), Bio-systems Engineering 93: 99-106. doi:10.1016/j.biosystemseng.2005.08.003

Sterman JD (2000) Business Dynamics, Systems Thinking and Modeling for a Complex World, Boston, Irwin McGraw Hill.

The World Bank (2015) Download Data, Retrieved from http://data.worldbank.org/country/iran-islamic-republic on 15 August 2015

Ventana Systems Inc. (2007) Vensim ${ }^{\circledR}$, User's Guide Version 5, 7, 78-80, Retrieved from http://is.bwl.unimannheim.de/index.php?option=com_docman\&task=doc_vie w\&gid=10 on 15 August, 2015. 